Revista Iberoamericana. Vol. LXIV, Núms. 182-183, Enero-Junio 1998; 55-80

\title{
EXCLUSÕES (E INCLUSÕES) NA LITERATURA LATINO-AMERICANA: ÍNDIOS, NEGROS E JUDEUS
}

\author{
POR \\ Lúcia Helena Costigan \\ The Ohio State University
}

À memória de Antonio Cornejo-Polar

Qualquer que se encarregar de escrever a História do Brasil, paiz que tanto promette, jamais deverá perder de vista quaes os elementos que ahi concorrão para o desenvolvimento do homem. (...) Não há dúvida que o Brazil teria tido um desenvolvimento muito differente sem a introdução dos escravos negros. Se para o melhor ou para o peior, este problema se resolverá para o historiador, depois de ter tido occasião de ponderar todas as influencias, que tiveram os escravos africanos no desenvolvimento civil, moral e político da presente população. (...) Jamais nos será permittido duvidar que a vontade da providencia predestinou ao Brasil esta mescla. $\mathrm{O}$ sangue portuguez, em um poderoso rio deverá absorver os pequenos confluentes das raças India e Ethiópica.

Karl Friedrich Phillip von Martius, "Como se deve escrever a História do Brasil" (1845).

I. O ENSAIO de Martius NA historiografia brasileira: Do PRÊMiO AO ENGAVETAMENTO

Se a invenção das tradições é uma das marcas registradas da modernidade, como sugere David Cannadine em seus estudos sobre rituais e cerimônias, ${ }^{1}$ a passagem acima, extraída do discurso fundacional da historiografia brasileira, além de corroborar a tese do teórico inglês, vai de encontro com o ponto de vista defendido por Eric Hobsbawm, de que as invenções e mitos modernos criados pelos românticos, "hunters of the past" e "creators of tradition" (100), estão marcados pela contradição.

\footnotetext{
'No ensaio "The Context, Performance and Meaning of Ritual..." Cannadine analisa o contexto monárquico britânico para sugerir que a invenção das tradições é um fenômeno da modernidade, motivado principalmente pela burguesia interessada na formação dos impérios e nações. A sede pela pompa, a grandiloqüência e o "theatre of power" (103), detectados por Cannadine na monarquia inglesa dos séculos dezenove e vinte, se aplicam muito ao ambiente latino-americano do mesmo período, principalmente à monarquia brasileira, onde a pompa e a ostentação ditaram as normas sociais e políticas.
} 
As afirmações da epígrafe que abre este ensaio, como muitas outras extraídas das narrativas do século dezenove, destinadas a explicar a nação como um órgão unificador e eliminador de diferenças, ajudam a compor o mapa do fenômeno ocidental denominado por David Sibley "Geographies of Exclusion". 2 As asserções também trazem no seu bojo as contradições que se fizeram e que se fazem presentes, tanto nas nações européias, quanto nas que integram o atual continente latino-americano.

Semelhante ao que ocorrera na Europa e na América Hispânica, também no Brasil o século dezenove marcou a "fundação e as fronteiras da cidadania". ${ }^{3}$ Como no caso das nações hispano-americanas, que se encontra documentado em La historiografía literaria del liberalismo hispano-americano del siglo XIX, de Beatriz González Stephan, a historiografia e a crítica literária brasileira se processaram por "las vías de un progresismo conservador" (178), cumprindo assim, "una función decisiva para la construcción ideológica de una literatura nacional, que servir[ía] a los sectores dominantes para fijar y asegurar los emblemas de la imagen de la unidad política nacional" (González 19). A visão "progressista conservadora" dos intelectuais brasileiros do século dezenove, forjada a partir de influências européias como o positivismo de Auguste Comte (1798-1857) e as teorias evolucionistas originadas nas teses de Charles Darwin (1809-1882) e Herbert Spencer (1829-1903), orientou, como uma bússola, o processo de seleção dos elementos e grupos étnicos que, no plano literário, integrariam o Brasil como comunidade-nação.

No intento de estabelecer uma genealogia das influências européias na literatura ficcional e historiográfica brasileira da segunda metade do século dezenove e da primeira parte do vinte, poder-se-ia traçar um mapa da formação do nacionalismo, onde intelectuais como Gonçalves de Magalhães (1811-1882 ), José de Alencar (18291877), Joaquim Manuel de Macedo(1820-1882)e José Pereira da Graça Aranha(18681931), situar-se-iam numa zona predominada pelas idéias de Jean Jacques Rousseau (1712-1778) e pelas teorias positivistas. A nostalgia pela natureza, a busca da virtude primitiva e o positivismo levaram esses escritores à defesa de um ideal patriótico, onde o nativo era visto como o único elemento que, juntamente com o português, havia contribuído positivamente para a formação étnica e cultural do povo brasileiro. Na obra desses escritores, o negro era eliminado ou apresentado como negativo para a nação. Nos escritos de críticos literários e historiógrafos como Sílvio Romero (1851-1914) e

\footnotetext{
${ }^{2} \mathrm{~A}$ análise de Sibley focaliza a maneira pela qual as sociedades dominadas pela cultura ocidental se aproveitam das diferenças para excluir ou para segregar determinados grupos humanos. Sibley lê a paisagem humana como "landscape of exclusion" (Geographies ix) e vê a monopolização do espaço como uma forma de poder. Neste texto poder-se-á ver que a elite dominante busca a monopolização do espaço não apenas no plano geográfico como também no plano textual. Naturalmente os grupos dominados nem sempre permanecem passivos nem deixam de influenciar a produção artística e literária dos setores dominantes.

${ }^{3}$ Aproveito-me aqui da metáfora utilizada por Susana Rotker para titular o número especial da Revista Iberoamericana, LXIII, 178-179, dedicada ao estudo crítico das produções literárias hispano-americanas do século dezenove.
} 
Afrânio Peixoto (1876-1947), onde as teorias evolucionistas parecem dar o tom mais forte, o elemento etiópico está presente, mas de forma passiva. Literariamente o negro não integrava a comunidade-nação sem antes passar pelo processo de branqueamento e de assimilação da cultura ocidental. Talvez por darem-se conta de que a maior parte da população era preta e de que o clareamento do Brasil somente ocorreria por meio da miscigenação, intelectuais como Sílvio Romero, optaram por promover a condição mulata do Brasil através do incentivo a uma política de imigração européia. A atitude de rechaço ao negro e de promoção do mulato se faz evidente no ensaio do crítico sergipano, "A emancipação dos escravos", publicado no dia quatro de agosto de 1881, no jornal $O$ Monitor. Ao afirmar que o negro era um elemento vencido na escala etnográfica e que o Brasil não era e nem deveria se transformar em um outro Haiti, Sílvio Romero defendia uma política de miscigenação que, apesar de promover o mulato, tinha por meta final o branqueamento do negro e não o empretecimento do branco. ${ }^{4}$ A postura elitista assumida pelos ideólogos da nação com respeito ao negro, sugere que, de maneira geral, os intelectuais brasileiros - familiarizados com o ensaio de Karl Friedrich Phillip von Martius (1794-1868), etnólogo alemão que vivera no Brasil entre os anos de 1817 e 1820 - acreditavam que "a introdução dos escravos negros" havia sido "para o pior" e não "para o melhor" (Martius 403). Decidiram, então, praticar um assimilacionismo onde o negro passaria por uma espécie de "ethnic cleansing" ou de limpeza de cor, de raça e de cultura.

Dentro do quadro assimilacionista, tanto os intelectuais de tendências proeminentemente positivistas, quanto os de maior inclinação ao evolucionismo darwinista defenderam um "enlightened" nacionalismo, onde o europeu branco era visto, simultaneamente, como o clareador da nova nação e o introdutor da cultura ilustrada, ao passo que o negro aparecia como um elemento indesejável no imaginário social da comunidade-nação.

Coincidindo cronologicamente com o período fundacional das histórias nacionais e literárias hispano-americanas, situado por González Stephan por volta de meados do dezenove, ${ }^{5}$ o ensaio de Martius ocupa um papel relevante dentro da historiografia brasileira. Primeiro, porque ao ser motivado pela inauguração do Instituto Histórico e Geográfico Brasileiro, fundado em 1838 pela elite pensante da nação-império, integra as cerimônias e rituais de invenção de tradţão nacional de que falam Cannadine e Hobsbawm. Segundo, porque foi o primeiro documento escrito para chamar a atenção à necessidade de reconhecimento da participação do negro na formação cultural e étnica do povo brasileiro.

${ }^{4}$ Esta referência ao discurso de S. Romero se encontra na obra, Race and Color in Brazilian Literature, de David Brookshaw (38). Brookshaw identifica como elitista e eurocêntrica tanto a atitude de intelectuais como $\mathrm{S}$. Romero que aceitavam a assimilação do negro, quanto a dos intelectuais nativistas, como Alencar, que não aceitavam a assimilação do negro. Brookshaw vê os primeiros como o "colonizer who accepts" (10) e os últimos como "blatant racists" (10). ${ }^{5}$ Nas palavras de González Stephan, ..."en Hispanoamérica alrededor de la década del 50 y del 60 van apareciendo las primeras historias literarias nacionales" (178). 
Criado por intelectuais empenhados em perscrutar o passado colonial a fim de definir o presente e o futuro da independente nação, o Instituto Histórico e Geográfico Brasileiro funcionou como uma das primeiras instituições modernas do Brasil, cuja função primordial era a coleta e o arquivo de dados relevantes para a construção do museu imaginário da recém independente nação. Partindo do pressuposto de que até então o Brasil não havia sido historiado como uma nação autônoma, os patriarcas da independência acreditavam que o novo país carecia de uma nova história. Foi esse projeto que motivou a criação do Instituto. Aos seus membros fundadores cabia esta missão. E. Bradford Burns deixa claro este ponto ao afirmar, em sua obra Perspectives on Brazilian History, que os membros do Instituto tinham como ponto fundamental responder à seguinte questão: “Como tal história deve ser escrita?” (21). ${ }^{6}$

Na busca de uma resposta para esta pergunta, crucial para a nova nação, os membros do Instituto convocaram uma sessão especial que teve lugar no dia 14 de novembro de 1840. Através de um dos seus membros-fundadores, Januário da Cunha Barbosa (1780-1846), convites foram enviados a pesquisadores de renome internacional, incentivando-os a apresentarem ensaios filosófico-metodológicos sobre um plano para se escrever a história do Brasil. O ensaio de Martius foi premiado como a melhor proposta.

Como já foi mencionado de passagem, o ensaio, que se encaixava dentro das manifestações tidas por Hobsbawm? como "invenções de tradição" que se popularizavam na Europa e nas Américas, era parte das novas estratégias destinadas a assegurar a identidade e a coesão de um determinado grupo social. No entanto, ao afirmar que seria um erro histórico e historiográfico ignorar a influência dos índios e, particularmente, a dos negros na formação cultural e étnica da nação, Martius expressava idéias muito além de seu tempo e, talvez sem que se desse conta, identificava, no contexto brasileiro do século dezenove, aquilo que Sibley interpreta como sendo "geografias de exclusão". Contraditoriamente, se por um lado o ensaio de Martius adiantava a tese do triplo amalgamento ou da miscigenação das raças branca, negra e índia, por outro, a escrita do ensaísta alemão tampouco ficou isenta das contradições e dos preconceitos característicos das narrativas que inventavam a nação. Ao mesmo tempo em que assumia uma atitude democrática, ao chamar a atenção para a necessidade de se

\footnotetext{
6 "How should such a history be written?" (Bradford Burns 21). Todas as citações de obras publicadas em inglês foram traduzidas por mim. Algumas das citações foram mantidas no idioma em que foram originalmente publicadas. Quando isso ocorre uma explicação em português antecede ou segue a passagem citada.

${ }^{7}$ No ensaio "Mass-Producing Traditions: Europe, 1870-1914", Hobsbawm observa que "political and social inventions of tradition" surgiram nos países onde a necessidade das mesmas se fizeram necessárias (264). Para Hobsbawm, as "invenções de tradição", aliadas à determinadas tentivas de modernização (the attempt to 'modernize') tinham o propósito de manter a antiga ordem de subordinação social (266). O estudo de Beatriz González sobre o contexto hispanoamericano encontra eco na análise de Hobsbawm sobre o ambiente europeu da segunda metade do século dezenove e primeiras décadas do vinte.
} 
reconhecer a participação do índio e do negro na cultura e no sangue do povo brasileiro, como se pode observar na passagem abaixo, o historiógrafo alemão não deixou de exibir uma postura eurocêntrica, ao atribuir ao português a superioridade cultural, moral e física:

Cada uma das particularidades physicas e moraes, que distinguem as diversas raças offerece a este respeito um motor especial: e tanto maior será a sua influência para o desenvolvimento commum, quanto maior for a energia, número e dignidade da sociedade de cada uma d'essas raças. D'isso necessariamente se segue o portuguez, que, como descobridor, conquistador e senhor, poderosamente influiu n'aquelle desenvolvimento; o portuguez, que deu as condições e garantias moraes e physicas para um reino independente; que o portuguez se apresenta como o mais poderoso e essencial motor (Martius 390).

Ao destacar o português como "descobridor, conquistador e senhor," e como "o mais poderoso e essencial motor" na formação da nação brasileira, Martius conferia ao europeu a supremacia racial e moral, vendo-o como agente catalizador das demais raças e culturas. Também, ao apontar o sujeito masculino como o principal elemento a ser beneficiado pelo desenvolvimento moderno, consciente ou inconscientemente, Martius excluía do seu discurso o elemento feminino, confirmando assim o que se tornou clássico através da obra de Benedict Anderson: que a comunidade-nação, imaginada e idealizada tanto pelos europeus quanto pelos criollos latino-americanos, privilegiava a cultura ocidental, a raça ariana, o gênero masculino e as religiões cristãs. Uma vez que, como sugere Anderson, o livro exerceu um papel fundamental na conformação da "camaraderia horizontal", a mulher, que de forma geral, não integrava o setor letrado, estava automaticamente excluída da "comunidade imaginada" pelos idealizadores de nações. A tese de Anderson, de fundamental relevância nesta leitura do ensaio de Martius e da produção literária e crítica brasileira do período em questão, encontra ressonância na crítica de teóricos como Edward Said e de Homi Bhabha que, a partir de uma postura pós-moderna e pós-colonialista, começaram a pôr em xeque os pressupostos ideológicos que nortearam os projetos das narrativas e políticas dos impérios e das nações dominadas pela cultura ocidental. ${ }^{8}$

${ }^{8}$ Em sua obra-mestra, Orientalismo, Said demonstra a forma pela qual, a partir do domínio do Atlântico-europeu, a cultura ocidental logrou "política, sociológica, científica, ideológica e imaginariamente fabricar o Oriente" (Orientalism 2). Em Culture and Imperialism, Said analisa as manifestações culturais dos modernos impérios ocidentais, a fim de destacar a forma pela qual produções literárias, e em especial as novelas de origem francesa e inglesa, influenciaram a literatura e as atitudes nas novas nações, onde o domínio cultural da Inglaterra e da França se tornaram fortes. Referindo-se à novela Said afirma: "I consider it the aesthetic object whose connection to the expanding societies of Britain and France is particularly interesting to study' (Culture xii). Tanto Said quanto Anderson influenciaram os estudos de Homi Bhabha e de outros críticos pós-modernos. Em "DissemiNation" Bhabha questiona a construção da cultura e da nacionalidade e sua filiação textual ao esclarecer: "What I am attempting to formulate in this 
Um outro aspecto que chama a atenção para o ensaio de Martius diz respeito à recepção do mesmo no meio intelectual brasileiro. Apesar de selecionado como o que melhor traçava as diretrizes para se escrever a história do Brasil moderno e progressista, as idéias defendidas por Martius ficaram engavetadas por quase um século, não chegando a influenciar, de maneira positiva, a literatura, a historiografia ou a crítica literária produzidas no Brasil durante a fase imperial, que se estendeu desde a independência, em 1822, até a proclamação da república, em 1889. No período que vai da proclamação da república até 1930 - ano da posse de Vargas, do deslatar da indústria e do assentamento das bases do Estado Novo implantado oficialmente em 1937 - tampouco se observa a influência das idéias de Martius na produção ficcional e historiográfica do Brasil.

Várias são as possíveis explicações para o fato das diretrizes traçadas por Martius não terem sido seguidas pelos intelectuais brasileiros da segunda metade do século dezenove e das primeiras décadas do vinte. Uma delas consiste na hipótese de que, ao chamar a atenção para a contribuição do nativo e do negro, Martius tocava diretamente na questão da raça e nos seus problemas afins, ponto melindroso e incômodo para a intelligentsia latino-americana de então, particularmente para a do Brasil, onde a população negra ultrapassava a de brancos. ${ }^{9}$

É possível que os escritores e os políticos do século dezenove, sentissem na pele a pigmentação da cor africana e/ou indígena, ou se encontrassem despreparados para confrontar as teorias fundamentalmente racistas que floresciam na Europa e que privilegiavam a raça ariana e a cultura européia. Entre essas, a do determinismo climático, postulada pelo inglês Henry Thomas Buckle (1821-1862), e a da

essay are complex strategies of cultural identification and discursive address that function in the name of "the people" or the "nation" and make them immanent subjects and objects of a range of social and literary narratives" (292) A noção de homogeneidade e de horizontalidade implícita no projeto de nação e de cultura modernas é desafiada por Homi Bhabha através do texto "A Question of Survival: Nations and Psychic States". Bhabha põe em xeque a noção de horizontalidade das modernas "comunidades imaginadas" ao afirmar que ". . the 'meaning' of culture that survives after postructuralism reveals that limits, and limitations, of that idea of cultural modernity contained in the concept of an ideal community being both homogeneous and horizontal" (89). A respeito do papel do romance ou da novela latino-americana nos projetos nacionalistas, inúmeros são os estudos recentemente publicados. Dentre esses, vale a pena destacar o de Doris Sommer, Foundational Fictions: The National Romances of Latin America (1991), o de Nicolas Shumway, The Invention of Argentina (1991) e os de Roberto Reis, The Pearl Necklace (1992) e A Permanência do círculo (1986).

${ }^{9}$ Através de uma citação de Pedro Octávio Carneiro da Cunha, Windmüller sugere à p.84, que por volta do final do primeiro reinado (1831) o Brasil tinha uma população de aproximadamente três milhões e que apenas um terço da mesma era livre. Isto significa que mais ou menos dois milhões dos habitantes deveriam ser negros, mulatos, índios ou mestiços tidos como escravos. Thomas Skidmore não apresenta figuras exatas mas aponta para o grande contingente negro, quando afirma que o Brasil era a maior colônia do Novo Mundo e a única em que a proporção de pretos era superior a cinquenta por cento da população" (45). 
degenerescência genética, presentes nas teses de Hippolyte Taine (1828-1893), Ernest Renan (1823-1892) e Arthur de Gobineau (1816-1882). Talvez os intelectuais brasileiros também se sentissem acanhados com a presença de Gobineau, autor do Essai sur l'inégalité des races humaines, que entre os anos de 1869 e 1870, ocupava um cargo diplomático no Brasil. Qualquer que seja a razão, os escritores e políticos do século dezenove preferiram engavetar a (incômoda) proposta de Martius, incluindo em suas teses de história, de literatura e de cultura brasileira o esquecimento e a exclusão, ingredientes que, de acordo com Renan, também entrariam na construção da nação.

Via de regra, as idéias defendidas pela elite latino-americana, como o ensaísta uruguaio José Enrique Rodó (1872-1917), e o criminalista e sociólogo brasileiro Raimundo Nina Rodriguez (1862-1906), não ficaram isentas da influência de Renan que, por volta de 1848 , havia destacado as qualidades superiores da raça ariana européia, colocando em detrimento todos os demais povos do mundo, em particular os semitas e dentre os quais os judeus, descritos por Renan como carentes de qualidades positivas. ${ }^{10} \mathrm{O}$ criminalista maranhense, autor de $O$ problema do negro na América portuguesa, alertou para as conseqüências culturais e raciais da miscigenação e, semelhante ao arielismo de Rodó, privilegiou o branco e a cultura européia. Diante de tais teorias e circunstâncias os letrados brasileiros e hispano-americanos se debatiam, não sabendo como incorporar dentro do projeto de nação os elementos ou grupos étnicos tidos por "exóticos", tais como os índios e os negros. Os nativos, que desde os tempos pré-colombinos e coloniais haviam habitado as terras americanas, foram estrategicamente transformados em tema central dos escritores românticos. A incorporação dos negros e dos judeus, que haviam desempenhado um papel relevante na formação étnica e cultural do povo brasileiro desde os primeiros séculos da colonização, foi a mais difícil de ser assumida pela elite que narrava a nação.

A leitura da tese de Martius e o posterior engavetamento e "esquecimento" da mesma pelos intelectuais brasileiros da época imperial e republicana, além de indicar, - como ditara Renan - que a nação também se constrói com o esquecimento, vai de encontro à observação de Hugo Achugar, de que "[l]a lectura ejercida por los críticos ha sido, fundamental aunque no únicamente, um modo de construir, destruir o preservar tradiciones." (14). Conforme poder-se-á ver a partir da segunda parte deste ensaio, ao inventar a nação e a tradição nacional, a elite intelectual do Brasil, seguindo o exemplo do que ocorria na Europa e nas demais nações latino-americanas, incluiu em suas narrativas ficcionais e historiográficas determinados grupos étnicos e excluiu outros.

Levando-se em consideração o impacto inicial do ensaio de Martius e o posterior silêncio com respeito ao mesmo, é possível conjecturar que, ao ponderarem sobre a

\footnotetext{
${ }^{10}$ Para um aprofundamento sobre as idéias de Renan com respeito aos judeus, consultar Jeffrey Lesser, Welcoming the Undesirables. Na obra Colonial Desire, Robert C. Young afirma que, para Renan, os semitas e os caucasianos eram uma raça inferior. Nas palavras de Young: "Caucasian and Semites were, in Renan's view, inferior. Renan suggested that ... Caucasian race was internally divided, fissured within and set against itself" (Young 69).
} 
proposta do etnólogo alemão e ao confrontarem-na com as teorias racistas, a intelligentsia brasileira, defensora dos valores ocidentais, preferiu engavetar a proposta para não admitir abertamente que, a seu ver, o índio e o negro representavam o "pior" para a nova nação.

\section{Da INCLUSÃo DO NATIVO NA FICÇÃo E NA HISTORIOGRAFIA BRASILEIRA}

Semelhante ao que ocorrera nas demais colônias que atualmente formam parte do continente latino-americano, nos anos anteriores e posteriores à independência o elemento nativo entrou no debate e nos escritos dos intelectuais brasileiros, mas de forma sublimada e mitificada. O indianismo, inspirado em Rousseau e nutrido pela nostalgia romântica herdada de Victor Hugo (1802-1885), tornara-se a moda da elite intelectual e política da época. O movimento de inspiração romântica germinou durante a regência de Dom Pedro I (1821-1831) e floresceu na do imperador Dom Pedro II (1831-1889). O próprio Dom Pedro I, não ficou imune à febre indianista. Após proclamar a independência do Brasil, em 1822, e garantir, através da constituição de 1824 , a igreja católica como a oficial do Brasil, o imperador ingressou na maçonaria e, ao fazê-lo, adotou como apelido o nome do último soberano asteca, Cuautémoc. Durante o reinado de Pedro II, quando o romantismo literário atingia a maturidade, o índio tornou-se o símbolo elegíaco das aspirações nacionais, transformando-se em tema poético para Domingos José Gonçalves de Magalhães (1811-1882), Antônio José Gonçalves Dias (1823-1864) e encontrando em José Martiniano de Alencar (18291877) o seu exponente máximo. Parece terem sido Francisco Adolfo de Varnhagen (1816-1878), Tobias Barreto (1839-1889) e Sílvio Romero os únicos letrados que não se deixaram contaminar totalmente pela febre indianista. " Apesar de não negarem a contribuição do nativo e da língua tupi na cultura brasileira, tanto Varnhagen quanto Sílvio Romero criticaram a parcialidade e o exagero de escritores como Alencar, que apresentavam o índio como o único elemento que, juntamente com o português, havia contribuído para a formação da etnia e da cultura brasileira. ${ }^{12}$ Em sua História da Literatura Brasileira Sílvio Romero censurou a ingratidão dos escritores que, "em

\footnotetext{
${ }^{11}$ Apesar de ter criticado o exagero do indianismo brasileiro, Varnhagen reconheceu a necessidade de se estudar as línguas dos nativos do Brasil. David T. Haberly documenta esse fato na sua obra Three Sad Races ao afirmar que "Varnhagen saw Tupi as a potential scientific language, useful for botany and zoology ..." (17).

${ }^{12}$ Em sua obra, The Indian in Brazilian Literature, David M. Driver explica que tanto Varnhagen quanto Romero se opuseram aos exageros do indianismo e admoestaram que na ordem de importância das três raças estavam o português, o negro e índio. (43). Driver acertadamente vê o indianismo como um movimento de ruptura com a coroa portuguesa: "Brazilians ardently desired not to be Portuguese; Lisbon's culture, along with her political domination, was to be discarded . . .once this cultural tradition was put aside, what remained but the Indian? So the nationalists turned to the barbarous Tupy and Guarany, proclaiming them the foundation of the nation's past an its hopes for the future" (41-42).
} 
obediência ao prejuízo da cor" (211), jamais quiseram do negro se ocupar ou admitir que tinham ascendência africana. Relatou com ironia o impacto e a extensão da febre indianista no século dezenove, febre que atacou até os mulatos, levando-os a ignorar a herança africana e a assumir uma falsa identidade indígena:

É velha a mania da 'nobreza tupinambá' de que muitos brasileiros são ainda em extremo affectados. No tempo da Independência, a moléstia chegou a seu auge, e vimos até mulatos, como o finado Francisco Gomes Brandão, tomarem nomes indígenas. Elle chamou-se Acayaba de Montezuma. Um disparate, como outro qualquer (Romero, História 1147).

Cabe aqui abrir um parágrafo para tratar mais detalhadamente da forma pela qual o índio foi incluído na literatura. Em Românticos e folcloristas, para provar que o índio idealizado por Alencar nada tinha que ver com o elemento nativo que ainda constituía uma parte significativa da população do Brasil, Renato Ortiz analisa O Guarani, obra que traduz o mito da fundação da brasilidade por excelência — demonstrando que o silvícola que habitava as regiões amazônicas e centrais não fora o que inspirara os escritores e os líderes políticos do século dezenove. Pelo contrário, os índios que ainda viviam nas terras brasileiras e que se definhavam física e moralmente ao entrarem em contacto com a civilização representavam, aos olhos da elite dirigente, uma séria ameaça ao organismo-nação. Um dos influentes contemporâneos de Alencar, o general Couto de Magalhães(1837-1898), expressou o desapontamento para com os índios vivos na sua obra $O$ selvagem. Na opinião do militar, o indígena constituía um entrave para o processo civilizatório e o maior perigo para os cristãos civilizados. Apelando diretamente ao leitor o general propôs um plano civilizatório íncola onde a destruição do nativo se efetuaria através da domesticação:

Chamo, entretanto, vossa atenção para a importância do problema da domesticação de nossos selvagens.... O território do nosso imenso Brasil é de duzentas e noventa e uma mil léguas quadradas. Quase duas terças partes desse território, ou cento e oitenta e duas mil e quatrocentas léguas quadradas, não podem ainda ser pacificamente povoadas por famílias cristãs, porque estão expostas às correrias sanguinolentas dos índios. (...) com a selvageria de um país quase ainda virgem, onde a raça branca não pode penetrar ... que arroste e destrua, por assim dizer, a primeira braveza de nossos sertões (Couto de Magalhães 14, 66).

De acordo com o ideal positivista que privilegiava a noção progressista e racionalista de história, o índio que se encontrava vivo e que se defendia contra as penetrações dos colonizadores era tido como um obstáculo a ser vencido, enquanto que o que havia sido dizimado ou o que se encontrava embrenhado no mato e em estado primitivo, possuía uma dimensão positiva (pois não ameaçava os civilizados). A cultura primitiva dos nativos, embora vista como inferior à da civilização industrialista, era tida como superior à dos grupos sociais que não se encaixavam bem, ou melhor dito, 
que não encontravam acolhida nos centros urbanos, espaços civilizatórios por excelência. Os elementos que não se ajustavam aos centros urbanos e ao sistema moderno, como os indivíduos desclassificados e subalternizados pela sociedade dominante, tais como os negros, os mulatos e os mestiços, eram tidos como "selvagens."

Comparando o contexto brasileiro com o europeu, é plausível associar os desclassificados do Brasil, tais como os escravos livres, os mulatos e os índios (vivos), com as classes trabalhadoras européias, estudadas por Louis Chevalier (1911-) e por Johann Gottfried Herder (1774-1803). No estudo de Ortiz, as teses de Chevalier e de Herder são recicladas a fim de mostrar que a elite européia via a classe obreira como "bárbaros" (Ortiz 88). Dentro do quadro comparativo que leva em consideração tanto as teses de Chevalier e de Herder quanto a interpretação de Ortiz, poder-se-ia dizer que, via de regra, no século dezenove, tanto na Europa quanto na América Latina, o contingente subalterno, formado por obreros europeus e desclassificados latinoamericanos tais como os escravos livres, os mulatos e os mestiços ocupavam um espaço intermediário, entre a cidade e a selva. No caso brasileiro, esse espaço intermediário podia corresponder às estradas e aos arrabaldes descritos por Laura de Mello e Sousa em sua obra Os desclassificados do ouro. Hoje em dia o espaço intermediário proposto por Sibley pode ser associado com as favelas, que se adentram pelas grandes cidades. De acordo com a linha de comportamento estabelecida pela cultura oficial, tanto no passado quanto no presente, os ocupantes dos espaços intermediários, por serem considerados improdutivos, personificavam o colonizado e a barbárie. A tese de Chevalier, que se apóia no modo de pensar da burguesia francesa para demonstrar que na cultura ocidental a classe obreira era tida como "selvagem" e como o maior perigo para a civilização, ${ }^{13}$ encontra eco nas Idéias sobre afilosofia da história da humanidade do alemão Herder. As idéias expressas por Herder e por Chevalier, de que os pobres e a ralé eram despossuídos de cidadania política, provavelmente influenciaram a intelligensia latino-americana na mitificação do índio desaparecido e na barbarização do índio vivo, do negro e do mulato—ocupantes por excelência dos chamados "espaços intermediários".

Cotejando a análise de Ortiz com a tese defendida por David Sibley através da obra Outsiders in Urban Societies, é atinente argumentar que os arredores e os arrabaldes

\footnotetext{
${ }^{13}$ C'est Buret, comparant la condition du prolétaire parisien à celle du sauvage et résumant par ce mot qui va dominer tout le reste de notre étude, comme il domine l'histoire de ce temps, aussi bien le fait précédemment mesuré, que l'opinion concernant le fait et le comportment qui résulte et du fait et de l'opinion. Sauvages, les ouvriers le sont par l'incertitude de leur existence, "premier trait de ressemblance qui rapproche le pauvre du sauvage, la vie est à la merci de chances du jeu, des caprices du hasard: aujourd'hui bonne chasse et salarie, demain chasse infructueuse ou chômage, aujourd' hui l'abondance et demain la famine." . . . cette masse d'hommes que l'industrie appelle autour d'elle, qu'elle ne peut pas occuper constamment, qu'elle tient toujours en réserve comme à sa merci. C'est dans les rangs de cette population, beaucoup plus nombreuse qu'on ne le suppose, que se recrute le paupérisme, cet ennemi menaçant de notre civilisation" (Chevalier 451-2).
} 
das cidades eram o espaço atribuído aos "outsiders" e aos "bárbaros". Sibley também observa que o elemento que se distancia, social e espacialmente, do grupo dominante e que se integra à natureza passa a ser tido como mítico. ${ }^{14}$ A tese da mitificação do nativo pelos românticos e modernistas brasileiros defendida por Brookshaw, Haberly e Ortiz vai de encontro com a de Sibley. A idéia de que o elemento que se distancia da sociedade dominante transforma-se em mito está presente na explicação de Brookshaw de que, tanto na literatura do romantismo quanto na do modernismo brasileiro, a transformação do índio em um mito nacional foi determinada pela "remoteness of the Indian and his isolation from the effects of colonial history" (Brookshaw 88)." Como se poderá ver mais adiante, o retrato que pinta Ortiz de José de Alencar, e o que pincela Haberly de Gonçalves Dias, deixam perceber que o índio foi o principal tema de inspiração para esses dois escritores românticos, porque para eles o silvícola se encontrava metaforicamente morto ou literalmente distante dos espaços urbanos. A admiração desses dois românticos brasileiros pelo índio morto também encontra eco na descrição de Michel de Certeau a respeito do colecionador interessado no passado em vias de extinção, que se contenta em admirar a beleza do morto. ${ }^{15}$

Em Geographies of Exclusion, além de destacar os subúrbios como o refúgio dos "eccentrics" e "outsiders", Sibley chama a atenção para o fato de que a linha demarcatória entre "o conformismo e a dissidência, o bem e o mal, a luz e a escuridão" $(40)^{16}$-em outras palavras, os padrões de comportamento estabelecidos pelas sociedades ocidentais a partir da Idade Moderna - constituía uma forma de isolar e/ou de eliminar minorias tidas como uma ameaça à hegemonia teológica da igreja oficial. De certa forma, a favela brasileira presta-se muito bem para exemplificar a tese de Sibley, pois é vista como refúgio de excêntricos e de marginais. Os estudos afrobrasileiros realizados pelo antropológo Roger Bastide (1889-1974) ${ }^{17}$ a respeito dos níveis de universos sagrados demonstram que, se por um lado o catolicismo, religião oficial da elite urbana, se identificava com o "sagrado domesticado", por outro, a religiosidade afro-brasileira dos negros, mulatos e mestiços das periferias urbanas, como o candomblé, correspondia ao "sagrado selvagem", que deveria ser contido ou eliminado.

Apesar de retoricamente bem argumentadas, a tese de Sibley e particularmente a de Brookshaw não explicam adequadamente o contexto social brasileiro e o latinoamericano em geral. Mesmo se a elite dirigente estabeleça linhas de comportamento e tente definir espaços geográficos e textuais para os diferentes grupos e classes sociais, no Brasil é desde os espaços intermediários ou periféricos que os grupos subalternos

14 "The mythical individual is removed from the dominant society and merges with nature" (Sibley 18).

${ }^{15}$ Ver M. de Certeau, La culture au pluriel.

16 "conformity and dissent, good and evil, light and darkness"(Sibley, Geographies of Exclusion 40).

${ }^{17}$ Conferir Bastide em Le Sacré Sauvage e Estudos afro-brasileiros. 
logram negociar o poder com a elite dominante. Rubens Ricupero fala com conhecimento de causa da sutil e profunda capacidade do setor popular atingir a elite, integrando o país étnica e culturalmente:

\begin{abstract}
No Brasil, mesmo em São Paulo, os bairros étnicos duram pouco, apenas o suficiente para que os moradores prosperem e se mudem para outras vizinhanças. Excetuando o Bexiga, invenção turística recente, os bairros italianos só existem hoje nas detestáveis caricaturas das novelas de televisão (falo com conhecimento de causa, pois nasci e vivi por mais de vinte anos no Brás, em São Paulo).-Qual será a razão dessa poderosa, irresistível capacidade de integração do Brasil ...? (...) Paradoxalmente, a explicação talvez se encontre na fraqueza generalizada das instituições formais do "país legal", escolas, educação física, igrejas, universidades, academias etc. e na força sutil mas profunda da vida popular, numa cultura informal envolvente e nãoexclusiva a qualquer grupo particular, na capacidade de absorção do "país real". ${ }^{18}$
\end{abstract}

Também no aspecto geográfico a linha demarcatória de espaços intermediários e periféricos no Brasil não é bem definida. Basta lembrar que em metrópoles como São Paulo e Rio de Janeiro encrustrações de favelados conseguem ocupar espaços urbanos centrais. Em Opovo brasileiro, Darcy Ribeiro (1922-1997) destaca que a urbanização no Brasil, "contribuiu para ... uniformizar os brasileiros no plano cultural, sem contudo, borrar suas diferenças" (21). O antropólogo cultural também chama a atenção para o fato de que, ironicamente, a estratificação de classe "que desgarra e que separa os brasileiros em componentes opostos ... é que, do lado de ... baixo, unifica e articula, como brasileiros, as imensas massas predominantemente escuras" (Ribeiro 444). Sendo assim, teses que apresentam linhas de comportamento e demarcações sócioespaciais de maneira tão rígida, não são de todo suficientes para explicar a realidade brasileira. Apesar da elite defender valores eurocêntricos, a cultura brasileira e as suas manifestações artísticas, inclusive a literária, estão fortemente marcadas pela influência popular. ${ }^{19}$

Os intelectuais do Brasil oitocentista, tais como Gonçalves Dias, Alencar e possivelmente a grande maioria dos membros fundadores do Instituto Histórico e Geográfico Brasileiro, são exemplos dos "românticos e folcloristas" descritos por Ortiz. Como tais, interessaram-se pelas culturas primitivas, representadas pelos índios arredios e pelos camponeses, recuperando-as como patrimônio histórico da nação, já que as mesmas funcionavam como um ícone que cumpria uma função simbólica no imaginário social da nova nação. Não é casual que o imperador Dom Pedro escolhesse o apelido Cuautémoc, nome do último soberano asteca, civilização que, física e temporalmente se distanciava da realidade brasileira, em vez de um nome aimoré ou guarani, grupos indígenas que no seu tempo habitavam o Brasil.

\footnotetext{
${ }^{18}$ Esta observação de Rubens Ricupero se encontra na p. xxxii do "Prefácio" da obra de Regina Igel, Imigrantes judeus/escritores brasileiros.

${ }^{19} \mathrm{O}$ estudo de Phyllis Peres incluído neste volume também questiona a validade da tese de Brookshaw na interpretação da realidade e da ficção brasileira.
} 
Como se pode inferir da frase de Couto de Magalhães citada previamente, as poucas referências aos índios vivos os apresentam como "um perigo" e como um entrave ao progresso. Portanto, a febre indianista da geração romântica foi o sintoma de uma grave enfermidade que atacou a elite brasileira, levando-a a matar, estratégica e metaforicamente, $o$ índio. Unicamente o índio morto entrou na literatura. Mas entrou como uma múmia, um artefato, uma lembrança do passado remoto e superado que havia cedido lugar a um Brasil moderno, civilizado e arianizado - como a Europa de Renan. Por isso, tem razão Ortiz quando afirma que "um sentimento de incongruência e de descompasso aflora" nas páginas dO Guarani (78). De forma geral, influenciada pelas teorias racistas emanadas da Europa, a intelligentsia brasileira reagiu contra o índio vivo, vendo-o como um "outsider" ou como um perigo que deveria ser eliminado para dar lugar ao progresso. A comparação que estabelece Ortiz entre os românticos do Brasil e os da Europa dá uma idéia clara do descompasso e da incongruência presentes nos mitos da fundação cultural e literária do novo país:

Os países europeus possuíam um passado histórico que servia de substrato para a imaginação romântica. Quando os irmãos Grimm retomam a canção de Niebenlungen, considerando-a a forma mais pura de poesia, eles recuperam um objeto histórico concreto, romantizando-o aos olhos do leitor. (...) Quando José de Alencar descreve uma situação medieval, o leitor sabe que tudo é ficção. Não há nenhuma correlação plausível com a história brasileira; seu passado encarrega-se de desmentir o embaralhamento dos fatos. A construção da identidade nacional, é neste sentido puramente alusiva, e deve voltar-se para o futuro, para o que se pretende criar, não para o que efetivamente ocorreu. (...) Num país onde as idéias se encontravam "fora do lugar" ... isto é, não se adequavam à realidade social como um todo, a fundação da civilização brasileira só podia existir como aspiração, nunca como testamento, ou prolongamento de acontecimentos antigos. (78-79) (...) O tratamento de Alencar acaba por promover valores como a castidade, a pureza, o amor assexuado. Poderíamos argumentar que são esses os temas dos romances de cavalaria, modelo para os escritores românticos europeus, o que não deixa em parte de ser verdadeiro. No caso brasileiro porém, o que está em jogo é algo que vai além das preocupações de cunho literário. Num país de negros, índios e mulatos, onde os exus estão soltos, a vigilância deve ser redobrada. A alvura e a virgindade não são apenas os ideais da Idade Média que não possuíamos, mas, para os pensadores da época, a condição necessária para nos libertarmos da barbárie. O ideal do branqueamento expressa o sonho de uma civilização européia nos trópicos (Ortiz 95).

Se por um lado, como se pode observar através do exposto acima, o índio (morto) foi incluído nas narrativas fundacionais, enquanto o que ainda habitava as terras brasileiras foi estrategicamente eliminado ou transformado em bárbaro pelos patriarcas românticos, por outro, como se nota no ensaio de Martius, o negro foi abominado. No caso do judeu a situação é ainda mais sutil e complexa. Para tratar do judeu na literatura brasileira é imprescindível abordar a questão do negro. De certa forma, a problemática do judeu na cultura brasileira imbrica-se com a do negro, principalmente a partir do 
contexto da Nova República (1930-1937) e do Estado Novo (1937-1945). A partir daqui, o texto tratará da questão do negro, alternando-a com a do judeu.

\section{DA INCLUSÃo DO NEGRO E DA EXCLUSÃo DO JUDEU}

Talvez sem que se desse conta das conseqüências de suas palavras, Martius acertou em cheio na questão da exclusão do negro, ao enfatizar que os ideólogos da independente nação não poderiam deixar de ponderar sobre "as influências ... dos escravos africanos no desenvolvimento civil, moral e político na presente população." (405). Contraditoriamente, refletindo os desencontros da época, Martius se esqueceu de incluir os judeus e cristãos-novos como um dos grupos étnicos que contribuíram na formação do povo e da cultura brasileira. Em parte, isto se explica porque no século dezenove a presença judaica era praticamente invisível no Brasil, devido às intensas perseguições da Inquisição portuguesa ocorridas a partir da descoberta de minas de ouro, no final do século dezessete e na primeira metade do dezoito. Apenas nas histórias e historiografias brasileiras escritas neste século, a contribuição judaica se faz presente. No campo literário apenas recentemente com as obras de críticos como Luiz Roberto Alves, Nelson H. Vieira e Regina Igel o vazio começa a ser preenchido. Portanto, a observação feita por Martius, há quase dois séculos atrás, de que "Qualquer que se encarregar de escrever a História [e a literatura] do Brasil, ... jamais deverá perder de vista quaes os elementos que ahi concorrer[am] para o desenvolvimento" (389) cultural é válida ainda para os dias atuais. ${ }^{20}$

Centrando mais pormenorizadamente no tema do negro na literatura brasileira, aceita-se aqui o ponto de vista - manifestado por inúmeros estudiosos, dentre os quais, do lado anglo-americano, Raymond Sayers, David Haberly e David Brookshaw- de que, via de regra, na prosa e na poesia brasileira do século dezenove, o negro é representado sob uma perspectiva paternalista e/ou elitista. ${ }^{21}$ Essas duas tendências predominantes se fazem presentes tanto na produção do período pré-abolicionista, ou

${ }^{20}$ A recuperação do elemento judeu no contexto brasileiro está sendo levada a cabo por historiadores como Anita Novinsky, K. Windmüller, Jeffrey Lesser, entre outros citados neste texto. No terreno literário a lacuna começa a ser preenchida com os trabalhos de críticos como Luiz Roberto Alves, Regina Igel e Nelson H. Vieira. Os estudos de L. R. Alves se limitam ao período colonial. Em Imigrantes Judeus: Escritores Brasileiros, R. Igel analisa textos "de narradores judeus no Brasil que incluem temas judaicos na sua escrita" (xxxv). O estudo de $\mathrm{N}$. H. Vieira, Jewish Voices in Brazilian Literature, apresenta uma postura crítica semelhante à de Bhabha e de Said. Através do aprofundamento na obra de Clarice Lispector, Moacyr Scliar e Samuel Rawet, Vieira alerta para a violência sócio-cultural presente na ideologia assimilacionista. Segundo Vieira as vozes e os discursos desses escritores judeus, "remind us of Brazil's failure to recognize or acknowledge otherness, and their discourses of alterity point to issues of equity that relate to injust cultural domination" (193).

${ }^{21}$ A visão paternalista e elitista do branco para como o preto, predominante na literatura brasileira, emerge nos textos: The Negro in Brazilian Literature de Raymond S. Sayers, Three Sad Races, de David T. Haberly, Race and Color in Brazilian Literature, de David Brookshaw. 
seja, anterior a 1888 , quanto na pós-abolicionista, que se estende até as primeiras décadas do século vinte. A tendência paternalista também é abordada por Thomas Skidmore. O historiador norte-americano afirma que "o negro aparecia na literatura romântica em papéis-padrão, como o 'escravo heróico', o 'escravo sofredor', [ao passo que] o homem livre de cor, que existia em todos os níveis da sociedade brasileira, era conspicuamente ignorado pelos escritores românticos " (23). A tendência elitista se faz clara na produção indianista de Gonçalves Dias e de Alencar, onde o negro e o mulato são representados como "nascidos para a escravidão", em contraste com o índio indômito e livre. No poema "Tabira," de Gonçalves Dias, a idéia do negro como protótipo do eterno colonizado, torna-se evidente:

\author{
Vivem homens de pel'cor da noite \\ Neste solo, que a vida embeleza; \\ Podem servos debaixo do açoite \\ Nénias tristes da pátria cantar. \\ Mas o índio que a vida só preza \\ Por amor dos combates e festas \\ Dos triunfos sangrentos e sestas \\ Resguardadas do sol no palmar (Gonçalves Dias 239) 22
}

Na novela Til de Alencar, o negro também aparece como nascido para a submissão e para o trabalho escravo, enquanto que o nativo, em seu estado puro, personifica a liberdade e a insubmissão. Analisando a vida e a obra de Alencar, Haberly conclui que para o romancista nordestino, " o indianismo era simplesmente uma estratégia lógica e efetiva na luta para criar uma história nacional completa e significante" (32) ${ }^{23} \mathrm{O}$ político e escritor cearense, que como outros intelectuais brasileiros do seu tempo se opusera à abolição da escravatura negra, aprovara a miscigenação branca e índia apenas como um fato histórico de um passado distante, e como uma metáfora da formação de um caráter nacional distinto. Esta postura ideológica se evidencia em $O$ Guarani onde os mestiços como Isabel, nascida da união branca eíndia, é o estereótipo da sensualidade e da paixão, ou seja, do "potencial explosivo" de que fala Roger Bastide e que é reciclado por Ortiz (87). Segundo esse ponto de vista eurocêntrico e elitista, a miscigenação era negativa, pois puxava para baixo os elementos híbridos, como os mulatos mestiços. Na análise realizada por Brookshaw, Haberly, Ortiz e Skidmore, os discursos alencarianos sugerem que ele temia as conseqüências de qualquer medida que, legal e socialmente, enfraquecesse as barreiras que separavam os brasileiros brancos das brutas massas de pretos.

22 Os versos de Gonçalves Dias também aparecem em Brookshaw, p. 23.

23 "Indianism was simply a logical and effective strategy in the struggle to create a meaningful and complete national history, to establish a conciousness of national separateness and worth, and to defend that new identity against the powerful cultural pressures from abroad" (Haberly 32-33). 
$\mathrm{Na}$ literatura do período pós-abolicionista, com o amadurecimento das teorias racistas e do imperialismo liberal europeu, tanto os positivistas quanto os evolucionistas ou seguidores do darwinismo social negaram ao elemento etiópico um papel étnico e cultural ativo, com respeito ao passado, ao presente e ao futuro da nova nação. Para os positivistas tais como Euclides da Cunha (1866-1909), defensores da integração nacional por meio dos estudos regionais e da miscigenação, o índio, e não o negro, representava a "rocha viva" da nova raça brasileira. Também para os evolucionistas, o negro constituía um problema. Por isso a imigração européia, destinada a clarear o Brasil étnica e culturalmente era por eles incentivada. Obras como Canaã de Graça Aranha (1868-1931) defendem a política oficial republicana de incentivo à imigração européia como o meio de "enlightenment" racial e cultural.

A tendência paternalista, que caracterizou mais fortemente os positivistas partidários da integração nacional, eclode nas obras Fruta do mato, de Afrânio Peixoto (18761947) e Os sertões, de Euclides da Cunha. Em contraste com o sertanejo e o caboclo, tidos como o resultado da união ameríndia e representantes sui generis da integração nacional, o negro seguia sendo o eterno escravo, subserviente e em total dependência do senhor branco.

Se o elitismo e o paternalismo prevaleceram na caracterização do negro durante o período pré e pós-abolicionista, o mulato, amplamente abordado pelas obras classificadas como realistas e naturalistas, não ficou isento do desdém. Orientados pelas teorias racistas que pregavam a degenerescência das raças, a grande maioria dos escritores da época praticou em seus escritos uma espécie de política eugênica, onde os perigos da mistura da raça se manifestavam através da aversão ao mulato, muitas vezes designado pejorativamente por "crioulo". Em novelas como Turbilhão de Coelho Neto (1830-1911), o mulato é a personificação do ressentimento e da inestabilidade psicológica. Na produção de escritores naturalistas como Aluízio Azevedo (1857-1913), Adolfo Caminha (1867-1897) e Júlio Ribeiro (1845-1890), o mulato é o elemento degenerado, dominado pelos instintos e desejos carnais que o aproximam da perversão e da bestialidade. ${ }^{24}$

Com respeito ao judeu, não se pode falar de sua inclusão na literatura do século dezenove. Apesar da contribuição dos hebreus nos mais diversos aspectos da vida brasileira desde os primeiros dias da colônia até o século dezoito, os poucos judeus e cristãos novos que entraram na historiografia e na crítica literária do período monárquico (1882-1889) e da República Velha (1889-1930) foram transformados em nativistas ou nacionalistas. Ao se adentrar no passado colonial Sílvio Romero identificou Bento Teixeira como um dos precursores do nacionalismo brasileiro, vendo a Prosopopéia como "a primeira afirmação do nacionalismo que nunca mais a arte pátria havia de abandonar" ("A literatura " 18-19). ${ }^{25}$ Na sua História da Literatura Brasileira, o

\footnotetext{
${ }^{24}$ Para um aprofundamento nas tendências e estereótipos do negro, presentes nos escritores brancos, consultar Brookshaw, especialmente, "The White Writer", 17-152.

${ }^{25}$ Nos meus estudos sobre os cristãos-novos na literatura brasileira observo duas tendências na crítica literária: uma que os cataloga como nativistas ou nacionalistas, outra que ao dar ênfase
} 
erudito crítico literário voltou a enfatizar o nativismo e a brasilidade de Bento Teixeira: "Na segunda metade do século XVI existiu em Pernambuco um homem, que é, depois de Anchieta, o mais antigo poeta brasileiro. Falo de Bento Teixeira Pinto". "O nosso nativismo tem quatrocentos anos de existência" (História 360, 362).

Do século dezenove, o único judeu ou cristão-novo que teve entrada na literatura brasileira foi o poeta e teatrólogo Antônio José da Silva. Sílvio Romero também analisou-lhe a obra —o teatro e a lírica entremeada nas comédias - identificando-lhe o estilo como tipicamente nacional:

O poeta tem expressões de uma intuição admirável de lirista (...) Por aí é que é um
dos nossos, um brasileiro (...) era a alma americana, ainda cheia de todas as ilusões
da infância, que ria pela boca do poeta. (...) Pelo lirismo é que foi um herdeiro de Gil
Vicente e de Camões. Essas notas estavam então mudas em Portugal, foi preciso que
um brasileiro as despertasse de novo, levando-as daqui, como recordação da infância,
como uma herança de família (Historia $437-40) .{ }^{26}$

Entre os poetas e ficcionistas do romantismo brasileiro, José Gonçalves de Magalhães se destaca como o primeiro a incluir o judeu ou cristão-novo em sua produção literária. Em sua famosa peça teatral, Antônio José ou o Poeta e a Inquisição, -encenada em 1838, ano que coincide com a fundação do Instituto Histórico e Geográfico Brasileiro- o espírito nativista de Magalhães emerge com vigor. Ao estudar o impacto da peça no circuito literário brasileiro, Käthe Windmüller observa que " [a] mais grave recriminação dos críticos à obra de Magalhães é não ter praticado um Romantismo puro, descontaminado de influências clássicas: ter feito tragédia em vez de drama, escrito em verso em vez de prosa ..." (71). Buscando entender o porquê de Magalhães ter escolhido por protagonista um judeu ou cristão-novo, a estudiosa da presença judaica no Brasil-colônia conjectura:

Considerando todas as sugestões que a realidade social do ambiente lhe oferecia indígenas, negros e mestiços- é surpreendente a opção de Magalhães por um protagonista branco, intelectual e judeu (na realidade cristão-novo) inexpressivo como representação antropológica da sociedade da época, uma abstração, um tipo inexistente na comunidade da população e dificilmente realizável como identificação (86).

Entre as possíveis respostas sugeridas por Windmüller a respeito da escolha de Magalhães, chamam a atenção as seguintes:

ao estético, classifica as suas obras como inferiores às dos escritores metropolitanos. José Veríssimo e Oliveira Lima estão entre os críticos que, a meu ver, "deixam de abordar aspectos ... que apontam para a experiência do letrado converso" na colônia (Costigan, "A experiência" 78).

${ }^{26}$ Esta passagem de Sílvio Romero também foi citada por K. Windmüller na p. 87. 


\begin{abstract}
"A vontade de influir na formação da sociedade reveste-se, principalmente em Magalhães, num dever muito consciente. A religiosidade cristã substituindo o panteon olímpico, a promoção das etnias nacionais, ..." (75). "Antonio José é o poeta brasileiro queimado pela Inquisição, com quem Magalhães se identifica; é o judeu perseguido por sua etnia e religião com quem as minorias discriminadas se identificam, ...” (79). "O momento pedia a formação de um panteon de heróis nacionais. Não os havia ainda e os historiadores como Varnhagen, aliados aos literatos, ainda estavam empenhados em criá-los" (93).
\end{abstract}

São convincentes as afirmações de que "[o] momento pedia a formação de um panteon de heróis nacionais"(93), de que Magalhães desejava "influir na sociedade" (75) e que "se identifica[va]" (79) com o poeta morto pela Inquisição. Windmüller também persuade quando afirma que "Magalhães produziu uma obra que ele queria moderna, moralista e socializante" (80). Entretanto, na análise que aqui se empreende não se vê na escolha de Magalhães interesse algum em "promover as etnias brasileiras" ou em identificar-se com "as minorias discriminadas" (79). Basta ler o poema "Invocação à Saudade" e a sua obra em prosa, Memória Histórica da Revolução da Província do Maranhão, mencionadas por Windmüller (84-85) para notar que, longe de promover as etnias brasileiras, Magalhães via o maior e o mais discriminado grupo étnico do Brasil do seu tempo com desdém e desprezo. No poema, o negro escravo, descrito como "desgraçado", recebe mofa e recriminação em vez da simpatia do vate romântico. Na Memória Histórica também se percebem as contradições dos mitos nacionais de que falava Hobsbawm. Ao descrever uma revolução ocorrida no Maranhão entre os anos de 1838 e 1840, Magalhães, que condenara o colonialismo português, não consegue deixar de exibir uma postura elitista e colonialista com respeito aos grupos subalternos. $\mathrm{O}$ iniciador do romantismo brasileiro usa a expressão "fascinoroso negro" para se referir a Cosme - escravo que realmente se opusera ao colonialismo, rebelando-se contra os maltratos do senhor branco e fundando no quilombo uma escola para outros quilombolas rebelados. Seguindo a tendência predominante nos demais românticos brasileiros, o indígena é o único elemento étnico que Magalhães resgata na sua escrita. No entanto, como os demais literatos e historiógrafos do seu tempo, o nativo é resgatado de forma nostálgica, como "vítima ilustre" (68) e parte de um passado longínguo e superado.

A escolha de Antônio José como protoganista da sua peça teatral nada teve que ver com a recuperação étnica do judeu. A leitura que aqui se faz da peça de Magalhães não encontra nenhum indício de que Magalhães "se identifica[sse] ...[com] o judeu perseguido por sua etnia e religião", conforme sugere Windmüller(79). O protagonista da peça de Magalhães é exatamente o oposto do Antônio José "judaizante, [que] berra[va] veleidades [e que representava] um perigo para a saúde nacional", descrito por Alberto Dinis na obra Vínculos do Fogo(43). O Antônio José criado por Magalhães passa pelo filtro cristão do letrado romântico e se transforma na peça em um intelectual orgânico, que comparte com o seu criador as crenças e os valores e da cultura ocidental. 
A etnia judaica do protagonista foi totalmente abafada por Magalhães. O resgate de Antônio José pelo iniciador do romantismo no Brasil se dá pelo fato daquele ter sido poeta, e não por ter sido um judeu "perseguido por sua etnia e religião" (79). O próprio título da peça deixa claro que é com o "Poeta" que Magalhães se identifica. No prólogo à tragédia e na cena II do ato 3 , isto se faz ainda mais evidente:

Desejando encetar minha carreira dramática por um assumpto nacional, nenhum me parecêo mais capaz de despertar as sympathias e as paixões trágicas do que este. As desgraças de um litterato, de um poeta, que concorrêo para a glória nacional, não podem deixar de excitar interesse e amor, ao menos em nosso Paíz. (86) ... Nós que somos Poetas e Philosophos,/Que temos de servir de exemplo,/Já que Deos nos dotou de algum talento. ${ }^{27}$

Num momento em que o Brasil acabava de oficializar o catolicismo como religião oficial, e que o judaísmo havia sido sufocado pelas intensas perseguições e expulsões de cristãos-novos das primeiras décadas do século dezoito, o judeu estava mais morto do que o índio, que se tornara artefato para os românticos. Além do mais, como já se destacou na primeira parte deste ensaio através das referências a Anderson, Said e Bhabha, a produção literária romântica e moderna havia sido montada a partir do parâmetro eurocêntrico-cristão. De acordo com essa perspectiva ideológica, toda e qualquer crença que não se encaixasse dentro da norma cristã era tida como superada, ou como "explosiva"-como definiu Bastide - e, portanto, inaceitável para os intelectuais românticos. Como líder de um grupo literário ligado ao círculo católico oficial, e como diplomata que passara os últimos anos de sua vida como ministro plenipotenciário na cidade de Roma, o patriarca da renovação nacionalista nas letras brasileiras só poderia ter resgatado Antônio José porque via neste um "literato", um "poeta" e um "philósopho" patriótico, arianizado e cristianizado. Uma declaração de Magalhães, encontrada no prefácio ao poema Suspiros Poéticos e Saudades serve para corroborar o argumento de que Antônio José da Silva não estava sendo recuperado por sua etnia judaica:

Pede o uso que se dê um prólogo ao Livro ... É um Livro de Poesias escritas segundo as impressões de lugares; ora assentado entre as ruínas da antiga Roma, ... ora na gótica catedral admirando a grandeza de Deus e os prodígios do Cristianismo.... Ora, nossa religião, nossa moral é aquela que civilizou o mundo moderno, aquela que ilumina a Europa, e a América: e só este bálsamo sagrado devem verter os cânticos dos poetas brasileiros (Gonçalves de Magalhães 88).

Somente a partir do Movimento Modernista Brasileiro, deflagrado com a Semana de Arte Moderna em 1922, —um ano antes que Francisco José de Oliveira Vianna (1883-1951) publicasse a Evolução do povo brasileiro, obra onde o arianismo se faz

${ }^{27}$ A peça de Gonçalves de Magalhães foi reproduzida na obra de Windmüller. A citação encontra-se à p. 9. O grifo é meu. 
presente, talvez até com mais força do que no romantismo - foi que o negro entrou para a literatura como um dos principais elementos temáticos, e que o judeu passou a ocupar o centro de debate da política de imigração idealizado pelos dirigentes do país. Oliveira Vianna, que na fase da Nova República e do Estado Novo tornara-se influente consultor jurídico e ministro, atribuía à antiga aristocracia rural brasileira uma origem germânica, herdada do lado godo e suevo do português e, posteriormente, do colonizador holandês. Ironicamente, o sociólogo estado-novista —que via o judeu como inassimilável, o negro como menos inteligente do que o indígena e este último como "absolutamente incivilizável" (165) - se esqueceu de computar o fato de que grande parte dos colonizadores brancos do Brasil holandês eram cristãos-novos e judeus sefarditas que antes de se instalarem no Nordeste haviam emigrado da Península Ibérica para a Holanda. Foi provavelmente desta população de suposta "origem germânica" que descenderam muitos membros da aristocracia brasileira louvada por Oliveira Vianna. ${ }^{28}$

Apesar do fato de que a preocupação com o elemento nativo também constituísse uma das tendências marcantes no modernismo brasileiro, conforme se observa no "Manifesto antropófago", de Oswald de Andrade (1890-1954), onde o "tupy, or not tupy ... [was] the question" (3), o negro ganhou força em obras como Macunaíma de Mário de Andrade (1893-1945), e nos escritos de Jorge de Lima (1895-1953) e Jorge Amado (1912-), entre outros que - influenciados pelos modernistas europeus e vanguardistas hispano-americanos que buscaram o exótico na África- trouxeram o elemento afro-brasileiro para o centro do debate modernista do Brasil.

Geralmente, a crítica literária destaca a recuperação do elemento africano como o aspecto mais inovador do modernismo brasileiro. Ao estabelecer, porém, uma analogia do modernismo com o romantismo brasileiro, é difícil descartar a metáfora da "permanência do círculo", usada por Roberto Reis para se referirà tendência conservadora e hierarquizante presente na ficção brasileira do século dezenove e vinte. Se, conforme se buscou destacar nas páginas anteriores, o romantismo incluiu o índio, mas de

\footnotetext{
${ }^{28}$ As pesquisas realizadas por Arnold Wiznitzer, C. R. Boxer e José Antônio Gonsalves de Mello permitem esta conclusão. Os dados recenseados por Wiznitzer apontam que por volta de $\mathbf{1 6 4 0}$ o número de judeus no Recife era duas vezes mais que o de cristãos. Boxer crê que cerca de cinqüenta por cento da população branca era judia. Gonsalves de Mello não aponta figuras exatas, mas baseado nas informações de cristãos e de cronistas da época admite que os judeus eram muito numerosos no Brasil holandês. No seu estudo sobre Os cristãos-novos na Bahia Anita Novinsky afirma que "os cristãos-novos deixaram-se envolver com maior docilidade pelo processo assimilatório" (5); K. Windmüller crê que a "relativa tranqüilidade [do Brasil colonial] contribuíra para a assimilação de cristãos-novos e cristãos-velhos por casamentos" (10). José Gonsalves Salvador reforça a hipótese da assimilação dos cristãos-novos e judeus pela elite colonial brasileira ao sugerir que "desde os albores o Brasil tornou-se . . . uma refulgente esperança para ...cristãos-novos e judeus portugueses" (1). Apesar de confundir os judeus com uma raça, Solidônio Leite Filho destaca a contribuição cultural dos judeus ao Brasil ao afirmar que: "Dos povos que aportaram à Nova Lusitânia, logo após o descobrimento, foram sem dúvida os judeus o que maior concurso prestou, nos primitivos tempos, à civilização brasileira. Provinham de uma das raças mais cultas da Península Ibérica" (99).
} 
maneira sublimada, -como o "noble sauvage" de Rousseau - o modernismo permaneceu no mesmo círculo do progressismo conservador ao recuperar o negro como um elemento exótico e irreverente, que nada tinha em comum com as pessoas escuras, sofridas e humildes que compunham a grande maioria da população brasileira. Brookshaw expressa bem este ponto de vista ao observar que no modernismo brasileiro "o preto se transforma essencialmente numa figura mítica, um produto da estética populista do seu próprio criador" (11). ${ }^{29}$ Reiterando a opinião crítica de estudiosos como Haberly e Sayers, entre outros, Brookshaw também sustenta que, via de regra, refletindo pura e simplesmente a atitude das classes dirigentes e a postura letrada do ocidente, os escritores mulatos do século dezenove e da primeira metade do vinte, tais como Cruz e Sousa (1861-1898), Machado de Assis (1839-1908), Jorge de Lima e Mário de Andrade, assumirarm a linha de comportamento do colonizador e da elite burguesa, sublimando-se e transformando-se mentalmente em mais brancos do que os próprios brancos.

Coincidentemente, foi também a partir do movimento modernista que o ensaio de Martius foi desengavetado pela intelligentsia brasileira. O responsável direto pela recuperação da tese de Martius foi o sociólogo Gilberto Mello Freyre (1900-1987), que se tornara famoso por sua tese da democracia racial brasileira. Discorrendo sobre o tema do multirracialismo social brasileiro, José Honório Rodrigues (1913- ) associa Martius com Gilberto Freyre, destacando porém o brasileiro pela nova rationale onde o europeu, o africano e índio eram vistos como igualmente valiosos:

E pela primeira vez o velho plano de Martius, do estudo do indígena, do colonizador português e do escravo negro na formação da família e da sociedade brasileira é plenamente realizado. Se Varnhagen seguiu o plano de Martius, seguiu-o apenas na colheita do material, mas foi Gilberto Freyre que, demonstrando uma enorme capacidade de interpretação, reuniu e relacionou os fatos numa caracterização geral da sociedade e da família brasileiras (Rodrigues 142).

Influenciado pelas idéias do seu mestre de antropologia Franz Boas - que defendia que a suposta inferioridade dos não europeus tinha explicação em fatores culturais e sociais, e não em biológicos, - e reagindo contra a os modernistas paulistas, Gilberto Freyre se fez conhecido por seu Manifesto Regionalista (1926) - de fundamental importância para a revitalização da novela regionalista. Entretanto, foi com a tese da democracia racial brasileira, popularizada através das obras Casa grande e senzala (1933) e Sobrados e mocambos (1936), que o sociólogo pernambucano se tornou nacional e internacionalmente famoso. Como já foi amplamente tratado pelos estudos críticos pós-modernos e, dentre os estudados neste texto, Brookshaw, Candido, Skidmore e Jeffrey Lesser, o valor prático da suposta democracia racial idealizada por Freyre não estava na promoção do igualitarismo racial, mas no reforço do ideal de

29 ".... the Afro-Brazilian becomes an essentially mythical figure, a product of the esthetic populism of his creator" (Brookshaw 11). 
branqueamento e, especialmente, na tentativa de mostrar que a elite intelectual - tida como branca e feudal, como destacara Oliveira Vianna - através do contacto com o índio e com o negro adquirira os traços culturais, principalmente do africano.

Os recentes ensaios de Candido sobre o nacionalismo e o regionalismo brasileiro aproximam ideologicamente os intelectuais românticos dos modernistas, e apontam para a "permanência do círculo", tanto no romantismo quanto no modernismo brasileiro. Observa-se tal aproximação quando o respeitado crítico brasileiro associa Gilberto Freyre com os românticos brasileiros e afirma que: "É o caso do nacionalismo, que o liga aos românticos e o leva a preferir, nas obras, a busca que contribui para a descoberta ou a confirmação de aspectos especificamente brasileiros; do que conduz a uma visão literária do Brasil" (Candido, Recortes 86). Num momento em que a cultura e a intelectualidade se encontravam sob a tutela de Getúlio Vargas (1883-1954), no afã de apresentarem um painel nacional imaginado, montado e projetado por uma ideologia que favorecia a integração à custa da diferenciação, os intelectuais do Estado Novo promoveram a tese de Freyre e a assimilação do negro, projetando assim um Brasil nacionalmente unido, racialmente democrático e harmônico. Paradoxalmente, o que soa totalmente contraditório dentro desse quadro pintado como racialmente democrático é o fato de que - justamente no momento em que a proposta de Martius estava sendo recuperada pela intelligentsia brasileira e quando se promovia a imigração européia e o igualitarismo racial —o judeu de nacionalidade européia, tenha sido visto como "indesejável" por influentes intelectuais brasileiros.

Através do estudo seminal e abrangente de Jeffrey Lesser, Welcoming the Undesirables: Brazil and the Jewish Question, o arguto historiador analisa com profundidade a situação do judeu no Brasil no período que corresponde ao do florescimento da literatura modernista. Inúmeras e mui coerentes são as explicações dadas por Lesser com respeito ao tema da política de exclusão do judeu durante o período do regime de Vargas. Dentre as mais pertinentes para o tema deste ensaio, destacam-se as que apontam para a política nacionalista de intelectuais como Afonso Arinos de Mello Franco (1870-1943) e Oliveira Vianna que, ao combinarem as noções de raça, etnicidade e geografia, viam os judeus como não-europeus, ou melhor, como não arianos. Uma vez que para esses e outros influentes intelectuais brasileiros o propósito da Segunda República era romper com os excessos de liberalismo da Primeira República e conter os impulsos das culturas primitivas ou não brancas, $o$ adjetivo "europeu", - que se transformara num construto exclusivamente ligado à raça ariana e à cor branca - excluía o judeu. E no contexto onde prevalecia o xenofobismo contra os não-arianos, o judeu, por sua origem semita e por ser considerado "neither black nor white" (Lesser 4), era visto como um problema para o branqueamento e um entrave para a arianização do país.

Como se destacou anteriormente, durante o romantismo o índio foi o elemento exótico transformado em mito, enquanto que o preto representava o bárbaro. No modernismo brasileiro, apesar do negro ter sido recuperado pela literatura, no imaginário social da nação o preto e todos os demais elementos que não se enquadravam dentro 
do padrão racial e cultural ariano eram vistos como primitivos e "bárbaros." Isto se traduz claramente na seguinte observação de Oliveira Vianna:

Los elementos bárbaros que forman nuestro pueblo están en proceso de rápida disminución a) por la situación estacionaria de la población negra; b) por el aumento continuo de los aflujos arios en los últimos tiempos; c) por un conjunto de selecciones favorables que aseguran, en nuestro medio, al blanco condiciones de vitalidad y fecundidad superiores a la de los hombres de otras razas (Oliveira Vianna 192).

Uma vez que membros da elite dirigente estavam determinados a eliminar os "elementos bárbaros" e a alvejar a população por meio do elemento ariano, o judeu, tido como culturalmente primitivo e de cor intermediária, "nem preto nem branco", representava um empecilho para o branqueamento e para "a realização do sonho de uma civilização européia nos trópicos" (Ortiz 95). O fato de que o judeu fosse considerado como um elemento citadino também contribuiu para a indesejabilidade do mesmo por membros da elite dirigente. Provavelmente influenciado por Herder, que julgava os judeus carentes de ideal patriótico e de sentimento de liberdade e honra por não apego ao solo, ${ }^{30}$ Oliveira Vianna pregava que a nobreza e a independência estavam ligadas à aristocracia rural, à agricultura e à posse da terra. Um vez que o judeu era tido como não ariano, não afeito à agricultura e não branco, no imaginário social projetado por intelectuais da cúpula dirigente, esse imigrante europeu se transformou no "elemento explosivo" de que fala Bastide, no "vilão" usurpador apontado por Herder ou no grupo urbano perigoso e "ameaçador da civilização" descrito por Chevalier nos seus estudos sobre as classes trabalhadoras da Europa. Lesser deixa claro que apesar das barreiras da política imigratória, milhares de judeus lograram entrar no Brasil, integrando-se muito bem à nova sociedade. Dessa forma, o nativismo generalizado dos intelectuais do Estado Novo se caracterizou pelo que Lesser define como "specific anti-semitism" (65), onde a imagem do judeu filtrada da Europa, "not the real Jew", era considerado como o "perigo" (3) para o ideal arianista previsto para florescer no país a partir da Nova República e do Estado Novo.

Neste momento em que a crítica tida como pós-modernista e pós-colonialista explora as diferenças e funciona como um diapasão nos debates crítico-literários, é necessário estar alerta para o risco da "permanência do círculo", ou da perpetuação das exclusões. Em seus últimos apontamentos o respeitado crítico latino-americano Antonio Cornejo-Polar (1936-1997) chama a atenção para o fato de que "el excesivo desnivel de la producción crítica en inglés - precisamente en el idioma de la hegemonía que habla para sí de lo marginal, subalterno, poscolonial— que parece ... tomar como materia prima la literatura hispanoamericana y devolverla en artefactos críticos sofisticados ... [está] generando una extraña crítica diglósica" (343-344).

\footnotetext{
${ }^{30}$ Nas palavras de Herder os judeus "were a people spoiled in their education, because they never arrived at a maturity of political cultivation on their own soil, and consequently not to any sentiment of liberty and honour" (336).
} 
Infere-se dos "apuntes" de Cornejo-Polar que esta "extraña crítica diglósica", além de marginalizar a produção literária latino-americana, exclui o intelectual latinoamericano que não fala o idioma hegemônico. Uma vez que este texto centra-se na questão das exclusões na ficção e na crítica latino-americana da modernidade, seria oportuno encerrá-lo sugerindo um adentramento na produção literária reunida como "pós-moderna", a fim de detectar se também nesta a tendência às exclusões continua presente. ${ }^{31}$

\section{BiBliografia}

Achugar, Hugo. "Parnasos fundacionales, letra, nación y estado en el siglo XIX". Revista Iberoamericana (Siglo XIX: Fundación y fronteras de la ciudadania, dirigido por Susana Rotker) LXIII/178-179, (enero-junio, 1997): 13-31.

Alves, Luiz Roberto. Confissão, poesia e inquisição. São Paulo: Ática, 1983.

Anderson, Benedict. Comunidaes imaginadas: Reflexiones sobre el origen y la difusión del nacionalismo. 1983. México: Fondo de Cultura Económica, 1991. Andrade, Oswald de. "Manifesto Antropófago". Revista de Antropofagia. Reedição da Revista Literária publicada em São Paulo-1a. e 2a. "Dentições" -1928-1929. Introdução de Augusto de Campos. São Paulo: Cia. Lythographica Ypiranga, 1976.

Bastide, Roger. Le Sacré Sauvage. Paris: Payot, 1975. Estudos Afro-Brasileiros. São Paulo: Perspectiva, 1973.

Bhabha, Homi K. "DissemiNation". Nation and Narration. London/New York: Routledge, 1994.

"A Question of Survival: Nations and Psychic States". Psychoanalysis and Cultural Theory: Thresholds. James Donald, ed. New York: San Martin Press, 1991.

Boxer, Charles R. The Dutch in Brazil, 1624-1654. Oxford: Clarendon Press, 1957. Brookshaw, David. Race and Color in Brazilian Literature. 1983. Metuchen, N.J. and London: The Scarecrow Press, Inc. 1986.

Burns, E. Bradford. Perspectives on Brazilian History. New York and London: Columbia University Press, 1967.

Candido, Antonio. Recortes. São Paulo: Companhia das Letras, 1993.

Cannadine, David. "The Context, Performance and Meaning of Ritual: The British Monarchy and the 'Invention of Tradition', 1820-1977'. The Invention of Tradition. Eric Hobsbawn e Terence Ranger, eds. 1983. Cambridge: Cambridge University Press, 1988. 101-164.

\footnotetext{
${ }^{31}$ Em estudo anterior observo que "un número creciente de novelas o "romances" históricos traen al centro del debate postmoderno y postcolonial voces y discursos que habían sido marginalizados por el canon" (Costigan, "El judío" 59). Vale a pena aprofundar nestas produções para ver se as vozes e discursos aparecem nostalgicamente e se as exclusões persistem.
} 
Certeau, Michel de. La culture au pluriel. Paris: Bourgeois, 1980.

Chevalier, Louis. Classes laborieuses et classes dangereuses à Paris pendant la première moitiè du XIXe siècle. Paris: Librairie Plon,1958.

Cornejo-Polar, Antonio. "Mestizaje e hibridez: Los riesgos de las metáforas. Apuntes". Revista Iberoamericana LXIII/180(Julio-Setiembre, 1997): 341-344.

Costigan, Lúcia Helena. "A experiência do converso letrado Bento Teixeira: Um missing link na história intelectual e literária do Brasil-colônia”. Revista de Crítica Literaria Latinoamericana, Año XX, 40 (2do. semestre de 1994): 77-92.

"El judío letrado: del Brasil postmoderno al colonial". Estudios: Revista de Investigaciones Literarias. Año 4, 8 (Julio-diciembre 1996): 59-70.

Dinis, Alberto. Vínculos do fogo: Antonio José da Silva, o Judeu, e outras histórias da Inquisição em Portugal e no Brasil. São Paulo: Companhia das Letras, 1992.

Driver, David Miller. The Indian in Brazilian Literature. New York: Hispanic Institute in the United States, 1942.

Gonçalves de Magalhães, Domingos José. Trechos escolhidos. Seleção e apresentação por José Aderaldo Castello. Rio de Janeiro: Livraria Agir Editora, 1961.

Gonçalves Dias, Antônio. Poesia completa e prosa escolhida. Rio de Janeiro: Aguillar, 1959.

Gonsalves de Mello, José Antônio. Gente da Nação: Cristãos-novos e judeus em Pernambuco, 1542-1654. Recife: Fundação Joaquim Nabuco/Editora Massangana, 1989.

González Stephan, Beatriz. La historiografia literaria del liberalismo hispanoamericano del siglo XIX. La Habana: Casa de las Américas, 1987.

Haberly, David T. Three Sad Races: Racial identity and national consciousness in Brazilian literature. Cambridge: Cambridge University Press, 1983.

Herder, Johann Gottfried. Outlines of a Philosophy of the History of Man. 1784. T. Churchill, trad. New York: Bergaman Publishers, 1966.

Hobsbawm, Eric. "Mass-Producing Traditions: Europe, 1870-1914". The Invention of Tradition. Eric Hobsbawn e Terence Ranger, eds. 1983. Cambridge: Cambridge University Press, 1988. 263-307.

Igel, Regina. Imigrantes judeus/Escritores brasileiros: o componente judaico na literatura brasileira. São Paulo: Perspectiva: Associação Universitária de Cultura Judaica: Banco Safra, 1997.

Leite Filho, Solidônio. Os judeus no Brasil. Rio de Janeiro: Editores J. Leite \& Cia., 1923.

Lesser, Jeffrey. Welcoming the Undesirables: Brazil and the Jewish Question. Berkeley: University of California Press, 1995.

Magalhães, Couto de. O selvagem. Ed. comemorativa do centenário da $1^{\mathrm{a}}$ ed. Belo Horizonte: Livraria Itatiaia, 1975.

Martius, Karl Friedrich Phillip von. "Como se deve escrever a história do Brasil". Revista do Instituto Histórico e Geográfico Brasileiro. Tomo 6(1845): 389-411. 
Novinsky, Anita. Cristãos-novos na Bahia. São Paulo: Editora Perspectiva: EDUSP, 1972.

Ortiz, Renato. Românticos e folcloristas. São Paulo: Editora Olho d'Água, 1992.

Reis, Roberto. A permanência do círculo: Hierarquia noromance brasileiro. Niterói: EDUFF; [Brasília]: INL, 1987.

Renan, Ernest. "What is a nation?" Nation and Narration. Homi K. Bhabha, ed. London and New York: Routldege, 1990. 8-22.

Ribeiro, Darcy. O povo brasileiro: A formação e o sentido do Brasil. São Paulo: Companhia das Letras, 1995.

Ricupero, Rubens. "Prefácio" à obra de Regina Igel, Imigrantes judeus/Escritores brasileiros: ocomponente judaicona literatura brasileira. São Paulo: Perspectiva: Associação Universitária de Cultura Judaica: Banco Safra, 1997.

Rodrigues, José Honório. Teoria da História do Brasil (Introdução Metodológica) 3. ed. São Paulo: Companhia Editora Nacional, 1969.

Romero, Sílvio. História da Literatura Brasileira. 6 vols. 6 ed. Rio de Janeiro: Livraria José Olympio Editora, 1960

“A literatura 1500-1900". Vol. I, Livro do Centenário. Rio de Janeiro: Imprensa Nacional, 1900. 18-19.

Said, Edward W. Culture and Imperialism. New York: Alfred Knopf, 1993. Orientalism. New York: Vintage Books, 1979.

Sayers, Raymond S. The Negro in Brazilian Literature. New York: Hispanic Institute in the United States, 1956

Sibley, David. Geographies of Exclusion: Society and Difference in the West. London and New York: Routledge, 1995.

Outsiders in Urban Societies. Oxford: Basil Blackwell, 1981.

Skidmore, Thomas. Preto no branco: raça e nacionalidade no pensamento brasileiro. Rio de Janeiro: Paz e Terra, 1976.

Vianna, Francisco José Oliveira. Evolución del pueblo brasileño. Traducción del original de Julio E. Payro. Prólogo de Rodolfo Rivarola. 1933. Buenos Aires: Imprensa Mercatali, 1937.

Vieira, Nelson H. Jewish Voices in Brazilian Literature: A Prophetic Discourse of Alterity. Gainsville: University Press of Florida, 1995.

Young, Robert C. Colonial Desire: Hybridity in Theory, Culture and Race. London and New York: Routledge, 1995.

Windmüller, Käthe. $O$ "Judeu" no teatro romântico brasileiro: uma revisão da tragédia de Gonçalves de Magalhães, Antonio José ou o Poeta e a Inquisição. São Paulo: Centro de Estudos Judaicos da FFCLH/USP, 1984.

Wiznitzer, Arnold. The Records of the Earliest Jewish Community in the New World. New York: American Jewish Historical Society, 1959. 